\title{
Competition, foreign direct investment and welfare ${ }^{\dagger}$
}

\author{
Arijit Mukherjee* \\ Nottingham University Business School, UK, CFGE, Loughborough University, UK, \\ CESifo, Germany, and GRU, City University of Hong Kong, Hong Kong \\ and \\ Uday Bhanu Sinha** \\ Department of Economics, Delhi School of Economics, India
}

Submission: September 2015

Revised version: November 2015

Accepted: December 9, 2015

\begin{abstract}
In contrast to the usual belief, we show that a lower product-market competition may make the consumers better off and increase welfare when foreign firms strategically choose between export and foreign direct investment (FDI). A lower product-market competition may increase consumer surplus and also welfare by inducing FDI. The higher welfare stems from the increase in production efficiency under FDI compared to export by the foreign firm.
\end{abstract}

Key Words: Competition; Consumer surplus; Foreign direct investment; Welfare

JEL Classifications: F21; F23; L13

* Correspondence to: Arijit Mukherjee, Nottingham University Business School, Jubilee Campus, Wollaton Road, Nottingham, NG8 1BB, UK.

Email: arijit.mukherjee@ nottingham.ac.uk; Fax: +44 (0)115 8466667

** Uday Bhanu Sinha, Department of Economics, Delhi School of Economics, University of Delhi, Delhi - 110 007, INDIA. Email: sinhauday@yahoo.com, Fax: +91-11-2766 7159.

\footnotetext{
$\dagger$ We thank an anonymous referee for helpful comments and suggestions. The usual disclaimer applies.
} 


\section{Introduction}

The text book view suggests that the competing firms gain from a lower productmarket competition at the expense of the consumers, which creates a concern for the antitrust authorities. We show that this view may not be correct in the presence of foreign direct investment (FDI), which dominates international trade in recent years (UNCTAD, 2006).

Considering an international oligopoly with endogenous decision on FDI and export, and measuring lower product-market competition by higher product differentiation as in Raith (2003), Aghion et al. (2005) and Sacco and Schmutzler (2011), to name a few, we show that a lower product-market competition increases the foreign firm's incentive for FDI. On one hand, a higher product differentiation tends to reduce consumer surplus and welfare by increasing local monopoly power of the firms. On the other hand, a higher product differentiation induces FDI and tends to increase consumer surplus and welfare by saving the trade cost under export. If the latter effect is stronger than the former, which happens if product differentiation does not decrease too much, a lower product-market competition increases consumer surplus and welfare.

The Schumpeterian view suggests that lower product-market competition may benefit the consumers by creating positive effects on innovation (Schumpeter, 1943), while Arrow (1962) suggests the opposite. There is another literature comparing the effects of different types of product-market competition, viz., Cournot and Bertrand, on welfare. It shows that whether welfare is higher under relatively more fierce competition, i.e., under Bertrand competition than under Cournot competition, may depend on the effects of competition on innovation (see, e.g., Singh and Vives, 1984, Delbono and Denicolò, 1990 and Qiu, 1997). Contrary to these papers, we show the 
effects of competition on FDI and welfare. While the above-mentioned papers mainly consider different number of firms and different product-market choice variables (viz., quantity and price) to capture the effects of competition, different degrees of product differentiation capture the effects of competition in this paper. Hence, in our paper, the number of firms and the product-market choice variables are the same under different product-market competition.

Symeonidis (2008) shows that a lower product-market competition may benefit the consumers in the presence of input market imperfection. Deltas et al. (2012) show that a lower product-market competition may benefit the consumers due to the "home market principle", which gives the cartel members preference for supplying their home markets. Mukherjee and Sinha (2014) show that a lower product-market competition may benefit the consumers in the presence of strategic trade policies. However, the effect of a lower product-market competition on FDI is responsible for increasing consumer surplus and welfare in our paper.

\section{FDI vs. export and product-market cooperation}

Assume that there is a foreign firm (firm 1), which competes with a domestic firm (firm 2) with a differentiated product in the domestic market. We assume that firm 1 can serve the domestic market either through export or through FDI. While export requires a per-unit trade cost, $t$, FDI requires a fixed investment, $F$. We normalize the marginal costs of production for both firms to zero.

We consider demand functions similar to Shubik and Levitan (1980), which allows us to focus only on the effects of competition by ignoring the love for variety effect of product differentiation. Assume that the inverse market demand function faced by the $i$ th firm is $P_{i}=1-(2-\gamma) q_{i}-\gamma q_{j}$, where $i, j=1,2, i \neq j$ and $\gamma \in[0,1]$ 
show the degree of product differentiation. As $\gamma$ decreases, it increases product differentiation and creates a lower intensity of competition. If $\gamma=0$, the products are isolated and if $\gamma=1$, the products are perfect substitutes.

We consider the following game. At stage 1, firm 1 decides whether to export or to undertake FDI. At stage 2, the firms choose their outputs simultaneously and the profits are realised. We solve the game through backward induction.

\subsection{Export by firm 1}

If firm 1 exports at stage 1 , firms 1 and 2 maximise $\underset{q_{1}}{\operatorname{Max}}\left(\mathrm{P}_{1}-t\right) q_{1}$ and $\underset{q_{2}}{\operatorname{Max}} P_{2} q_{2}$ respectively to determine their outputs. The equilibrium outputs are $q_{1}^{x^{*}}=\frac{4-2 t(2-\gamma)-3 \gamma}{(4-\gamma)(4-3 \gamma)} \quad$ and $\quad q_{2}^{x^{*}}=\frac{4-(3-t) \gamma}{(4-\gamma)(4-3 \gamma)} . \quad$ We $\quad$ assume $\quad$ that $t<\frac{3(1-\gamma)}{2(2-\gamma)} \equiv \bar{t}(\gamma)$, which ensures that the outputs of both firms are always positive.

The profits of firms 1 and 2 are

$$
\pi_{1}^{x^{*}}=\frac{(2-\gamma)[4-2 t(2-\gamma)-3 \gamma)]^{2}}{(4-\gamma)^{2}(4-3 \gamma)^{2}} \quad \text { and } \quad \pi_{2}^{x^{*}}=\frac{(2-\gamma)[4-(3-\mathrm{t}) \gamma]^{2}}{(4-\gamma)^{2}(4-3 \gamma)^{2}}
$$

Consumer surplus, welfare of the domestic country and world welfare are respectively

$$
\begin{gathered}
C S^{x^{*}}=\frac{1}{6}\left[\frac{3 t^{2}(1-\gamma)}{(4-3 \gamma)^{2}}+\frac{3(2-t)^{2}}{(4-\gamma)^{2}}\right], \\
D W^{x^{*}}=\pi_{2}^{x^{*}}+C S^{x^{*}} \text { and } W W^{x^{*}}=\pi_{1}^{x^{*}}+\pi_{2}^{x^{*}}+C S^{x^{*}} .
\end{gathered}
$$




$$
\begin{gathered}
\text { We } \quad \text { get } \quad \frac{\partial\left(C S^{x^{*}}\right)}{\partial \gamma}=\left[\frac{t^{2}(2-3 \gamma)}{2(4-3 \gamma)^{3}}+\frac{(2-t)^{2}}{(4-\gamma)^{3}}\right]>0, \\
\frac{\partial\left(D W^{x^{*}}\right)}{\partial \gamma}=\frac{1}{8}\left[\frac{3 t(2+t)}{(4-3 \gamma)^{2}}+\frac{(4-t)(2-t)}{(4-\gamma)^{2}}\right]>0 \\
\frac{\partial\left(W W^{x^{*}}\right)}{\partial \gamma}=\left[\frac{t^{2}(5-3 \gamma)}{(4-3 \gamma)^{3}}+\frac{(2-\gamma)(2-t)^{2}}{2(4-\gamma)^{3}}\right]>0 \text { for } t \in[0, \bar{t}] .
\end{gathered}
$$

The following lemma is immediate from the above discussion.

Lemma 1: If firm 1 exports, higher production differentiation (i.e., a lower $\gamma$ ), implying lower product-market competition reduces consumer surplus, domestic welfare and world welfare.

Higher product differentiation gives both firms more monopoly power, thus reducing consumer surplus, domestic welfare and world welfare.

\subsection{FDI by firm 1}

Under FDI, firms 1 and 2 maximise $\underset{q_{1}}{\operatorname{Max}} \mathrm{P}_{1} q_{1}-F$ and $\underset{q_{2}}{\operatorname{Max}} P_{2} q_{2}$ respectively to determine their outputs. The equilibrium outputs are $q_{1}^{\mathrm{F}^{*}}=q_{2}^{F^{*}}=\frac{1}{4-\gamma}$.

The profits of firms 1 and 2 are

$$
\pi_{1}^{F^{*}}=\frac{2-\gamma}{(4-\gamma)^{2}}-F \quad \text { and } \quad \pi_{2}^{F^{*}}=\frac{2-\gamma}{(4-\gamma)^{2}}
$$

Consumer surplus, welfare of the domestic country and world welfare are respectively

$$
C S^{F^{*}}=\frac{2}{(4-\gamma)^{2}}
$$

$D W^{F^{*}}=\pi_{2}^{F^{*}}+C S^{F^{*}}$ and $W W^{F^{*}}=\pi_{1}^{F^{*}}+\pi_{2}^{F^{*}}+C S^{F^{*}}$. 
We get that $\frac{\partial\left(C S^{F^{*}}\right)}{\partial \gamma}=\frac{4}{(4-\gamma)^{3}}>0, \quad \frac{\partial\left(D W^{x^{*}}\right)}{\partial \gamma}=\frac{1}{(4-\gamma)^{2}}>0 \quad$ and $\frac{\partial\left(W W^{x^{*}}\right)}{\partial \gamma}=\frac{2(2-\gamma)}{(4-\gamma)^{3}}>0$

The following lemma is immediate from the above discussion.

Lemma 2: If firm 1 undertakes FDI, higher production differentiation reduces consumer surplus, domestic welfare and world welfare.

The reason for Lemma 2 is similar to that Lemma 1.

\subsection{The incentive for FDI}

Firm 1 undertakes FDI if $\pi_{1}^{x^{*}}<\pi_{1}^{F^{*}}$ or

$$
F<\frac{4 t(2-\gamma)^{2}[4-t(2-\gamma)-3 \gamma]}{(4-\gamma)^{2}(4-3 \gamma)^{2}} \equiv \bar{F}(\gamma)
$$

i.e., if the cost of FDI is less than $\bar{F}(\gamma)$, which is firm 1's maximum willingness to invest for FDI for a given product differentiation.

Proposition 3: Higher product differentiation increases Firm 1's incentive for FDI.

Proof: We $\quad$ get that $\frac{\partial \bar{F}(\gamma)}{\partial \gamma}=\frac{4 t(2-\gamma)[(4-3 \gamma)(8-3(2-\gamma) \gamma)-\mathrm{t}(2-\gamma)(16-\gamma(8-3 \gamma))]}{(4-\gamma)^{3}(4-3 \gamma)^{3}}>0$ for $t \in[0, \bar{t}]$ which proves the result. 
Higher product differentiation increases firm 1's profits under both export and FDI. However, the increase in profit is higher under FDI than under export due to the distortion created by the trade cost under export.

\subsection{The effects of higher product differentiation}

Figure 1 plots consumer surplus under FDI and export by firm 1.

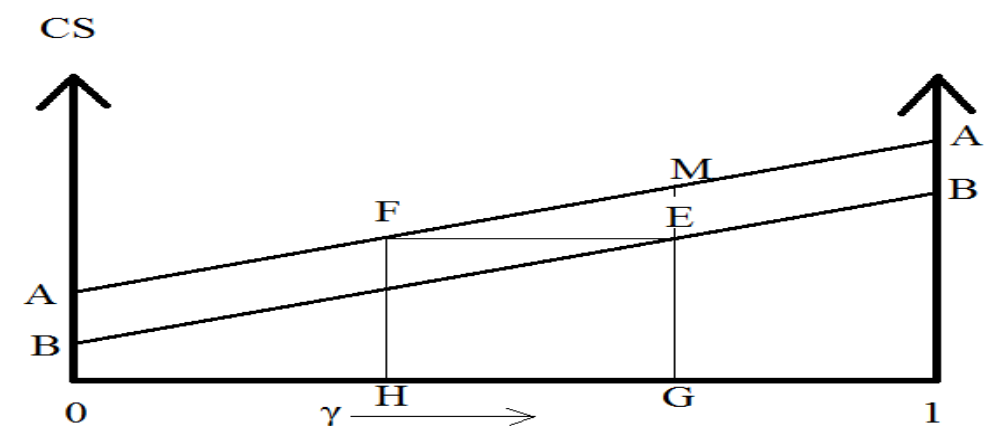

Figure 1: The effects of product differentiation on consumer surplus

In Figure 1, the lines $A A$ and $B B$ show consumer surplus under FDI and export by firm 1 respectively. We draw these lines as straight lines, for simplicity of exposition. It is easy to check from (2) and (4) that, for a given $\gamma$, consumer surplus is higher under FDI than under export by firm 1. It is immediate from Figure 1 that if product differentiation increases, thus creating lower product-market competition, it decreases consumer surplus if firm 1 either exports or undertakes FDI irrespective of the level of product differentiation. This happens since higher product differentiation increases local monopoly power of the firms.

An interesting situation arises if lower product differentiation induces firm 1 to switch from export to FDI. To see this, assume that the degree of product differentiation is $G$ and firm 1 exports. Consumer surplus in this situation is given by 
point $E$. Now consider that product differentiation increases in a way so that the new product differentiation parameter falls between $G$ and $H$ and firm 1 switches the mode from export to FDI. In this situation, consumer surplus is given by the points between $M$ and $F$ on line $A A$. It is clear from Figure 1 that higher product differentiation increases consumer surplus in this situation.

If product differentiation increases in a way so that the new product differentiation parameter is less than $H$ and firm 1 switches from export to FDI, higher product differentiation decreases consumer surplus.

If product differentiation induces firm 1 to undertake FDI, on one hand, higher product differentiation increases the firms' local monopoly power and tends to decrease consumer surplus. On the other hand, if higher production differentiation induces firm 1 to undertake FDI, it saves the trade cost and tends to increase consumer surplus. If product differentiation does not fall too much but it induces FDI, it creates a stronger latter effect than the former and higher product differentiation increases consumer surplus. However, higher product differentiation decreases consumer surplus if the former effect is stronger than the latter.

Since domestic welfare decreases with higher product differentiation and its value under FDI by firm 1 is higher than that of under export by firm 1, we can say that a lower product-market competition due to a higher product differentiation increases domestic welfare if it induces FDI by firm 1 and the benefit from trade cost saving is higher than the loss from the firm's increased local monopoly power.

Finally, consider the effect of a higher product differentiation on world welfare, which is the summation of domestic welfare and net profit of the foreign firm. We find from (1) that $\frac{\partial \pi_{1}^{x^{*}}}{\partial \gamma}<0$ for $t \in[0, \bar{t}]$, implying that higher product 
differentiation, say, from $\gamma_{0}$ to $\gamma_{1}$, where $\gamma_{1}<\gamma_{0}$, increases firm 1 's profit under export. If higher product differentiation, $\gamma_{1}$, induces firm 1 to undertake FDI, its profit under "FDI with $\gamma_{1}$," is higher than its profit under "export with $\gamma_{1}$,", which is higher than its profit under "export with $\gamma_{0}$ ". It is then immediate that if higher product differentiation increases domestic welfare by inducing FDI by firm 1, it also increases world welfare.

The following proposition summarises the above discussion.

Proposition 2: If lower product-market competition due to higher product differentiation induces FDI by the foreign firm, it increases consumer surplus, domestic welfare and world welfare if the benefit from trade cost saving is higher than the loss from higher monopoly power.

\section{Conclusion}

In contrast to the usual belief that a lower product-market competition decreases consumer surplus and welfare, we show that a lower product-market competition may increase consumer surplus and welfare by attracting FDI which helps to improve cost efficiency in the industry. Thus, our paper provides an important insight for antitrust authorities in framing competition policies. It is important to note that the welfare gain in our paper is not due to the standard "tariff jumping" benefit from FDI, where the degree of competition remains the same under pre and post era of FDI. 
To prove our point, we consider a demand structure where the degree of product differentiation does not affect the total demand, ${ }^{1}$ thus ignoring the effects of love for variety. However, if one considers a demand structure where higher product differentiation increases total demand, thus incorporating the effects of love for variety, ${ }^{2}$ it is immediate that a lower product-market competition due to a higher product differentiation increases the possibility of a higher consumer surplus and welfare by increasing the total demand.

\section{References}

Aghion, P., N. Bloom, R. Blundell, R. Griffith and P. Howitt, 2005, 'Competition and innovation: an inverted-U relationship', Quarterly Journal of Economics, 120: 701-728.

Arrow, A.J., 1962, 'Economic welfare and the allocation of resources for inventions', in $\mathrm{R}$. Nelson (Ed.), The rate and direction of inventive activity, Princeton, NJ: Princeton University Press.

Delbono, F. and V. Denicolò, 1990, 'R\&D investment in a symmetric and homogeneous oligopoly', International Journal of Industrial Organization, 8: 297-313.

Deltas, G., A. Salvo and H. Vasconcelos, 2012, 'Consumer-surplus-enhancing collusion and trade', Rand Journal of Economics, 43: 315-28.

Mukherjee, A. and U.B. Sinha, 2014, 'Export cartel and consumer welfare', Mimeo, Nottingham University Business School.

\footnotetext{
${ }^{1}$ Adding the demand functions of this paper, we get that $\left(q_{1}+q_{2}\right)=\left(1-\frac{P_{1}+P_{2}}{2}\right)$, which is independent of $\gamma$.

${ }^{2}$ See, e.g., Singh and Vives (1984) and Qiu (1997) for demand functions considering significant love for variety effects.
} 
Qiu, L., 1997, 'On the dynamic efficiency of Bertrand and Cournot equilibria', Journal of Economic Theory, 75: 213-29.

Raith, M., 2003, 'Competition, risk, and managerial incentives,' American Economic Review, 93: 1425-1436.

Sacco, D. and A. Schmutzler, 2011, 'Is there a U-shaped relation between competition and investment?', International Journal of Industrial Organization, 29: 65-73.

Schumpeter, J.A., 1943, Capitalism, socialism and democracy, London, Unwin University Books.

Shubik, M., and R. Levitan, 1980, Market Structure and Behaviour, Cambridge, MA: Harvard University Press.

Singh, N. and X. Vives, 1984, 'Price and quantity competition in a differentiated duopoly', Rand Journal of Economics, 15: 546-54.

Symeonidis, G., 2008, 'Downstream competition, bargaining and welfare', Journal of Economics and Management Strategy, 17: 247-270.

UNCTAD, 2006, World Investment Report: FDI from developing and transition economies: implications for development, United Nations, New York and Geneva. 